\title{
Liselotte Højgaard: Hvordan får vi verdens bedste sundhedsvæsen?
}

Informations Forlag, 2017, 88 sider

Anmeldt af Lars Thorup Larsen, lektor, Institut for Statskundskab, Aarhus Universitet

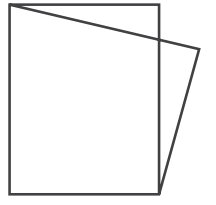

I sin nye bog rejser Liselotte Højgaard (LH), overlæge på Rigshospitalet og formand for Danmarks Grundforskningsfond, det ambitiøse spørgsmål: “Hvordan får vi verdens bedste sundhedsvæsen?". Det har vi ikke nu, for bogen beskriver i høj grad et sundhedsvæsen i krise. Bogen er generelt velskrevet, vedkommende og overraskende kort set i forhold til det ambitiøse spørgsmål, den rejser og forsøger at give nogle kvalificerede bud på. Ikke desto mindre vil jeg i det følgende forholde mig kritisk til dele af bogens argument, mens det samtidig er hensigten at fremdrage de elementer i diskussionen, der kan tænkes at have bredere relevans for professionsforskningen.

Forfatteren karakteriserer ikke selv sundhedsvæsenets problemer eller de foreskrevne løsninger som en professionskamp. Det til trods er der alligevel grund til at diskutere dem i den sammenhæng her, fordi de grundlæggende knytter sig til autoritetsforholdet mellem forskellige faggrupper og deres respektive vidensformer. Ét af LH's gennemgående argumenter er, at tid og ressourcer slet ikke kan følge med patienternes behov i dagens sundhedsvæsen. Dels køres der langt flere patienter igennem end tidligere, og dels bruges en unødigt stor del af ressourcerne efter LH's opfattelse på unødig administration, ansættelse af D」ØF'ere og på indførsel af gentagne kavalkader af de nyeste jubelagtige ledelseskoncepter i en professionel praksis, der ikke har plads til den slags.

Som eksempel beskriver bogen en frustreret yngre overlæge, der beklagede sig til LH over selv at skulle indsende bilag og lave rejseafregning set i forhold til personens formodentlig ret høje 
timeløn, som efter alt at dømme også har betalt den tid, der blev brugt på at skrive en lang mail om problemerne. Det er ikke svært at sætte sig ind i lægens frustration, men det er alligevel ret uklart, hvad vi mere generelt kan lære om sundhedsvæsenet af historien. For det første peger det vel ikke ligefrem på, at der er for meget, men snarere for lidt administrativt personale ansat, siden lægen selv skal lave det? For det andet og måske mere afgørende: Siger det egentlig noget særligt om sundhedsvæsenet? Mig bekendt gælder det i stort set alle offentlige organisationer - muligvis også private - at der både holdes skarpt øje med de ansattes brug af skatteborgernes penge, og at man samtidig har erstattet mellemlag af HK'ere med IT-systemer, hvor de ansatte selv indtaster, uploader, osv. Man kan bestemt diskutere, hvor godt den slags systemer fungerer i praksis, men at det generelt skulle være helt unødvendigt at kontrollere offentligt ansattes tjenesterejser forekommer måske ikke som det stærkeste argument, når det kommer fra Rigshospitalet.

Hvis vi ser på de løsningsforslag, der gives i bogen, handler de mere generelt om at skære store mængder administration væk og føre ledelseskompetencen tilbage til 'fagligheden'. Selvom det ikke defineres eksplicit, er der næppe tvivl om, at LH med faglighed mener noget, læger har, og som DJØF'ere i hvert fald ikke har. Bogen fremhæver Holland og til dels Schweiz som forbilleder, hvor en sådan faglig ledelse enten er gennemført ved reformer, eller hele tiden har været der. Desuden anbefaler LH en serie af tværgående redskaber til benchmarking i sundhedsvæsenet, dels knyttet til udredning af best practices inden for hvert område og dels knyttet til styring af hospitalsafdelinger efter en række parametre, der er mere i overensstemmelse med medicinsk faglighed end den nuværende styring.

Hvis vi begynder med styringsredskaberne, er der igen noget umiddelbart genkendeligt ved LH's kritik af New Public Management og beslægtede paradigmer i sundhedsvæsenet. At kritikken er velkendt, også fra mange andre områder af velfærdsstaten, der intet har med sundhed at gøre, gør den naturligvis ikke mindre vedkommende eller valid. Alle siger i dag, at de vil væk fra NPM og dens medfølgende skepsis og arsenaler af resultat- og dokumentationskrav. Det vanskelige er imidlertid at foreskrive et alternativ, der ikke enten bare er en ny version af det samme ligesom de ti forrige 'opgør' med NPM, eller som blot er en lettere diffus appel om at erstatte målstyring med en ny tillid til varme hænder i de udførende led. LH's løsningsforslag til fremtidens sundhedsvæsen gør begge disse ting på samme tid. Dels er bogen på den ene side meget ærlig om, at den drømmer sig tilbage til sundhedsvæsenet før DJØF'erne og resultatstyring satte ind i 1990'erne og frem; og dels kommer forfatteren som nævnt med en række forslag til nye tværgående styringsredskaber og ledelseskommissioner, bl.a. i forhold til gennemgang af best practices for alle sundhedsvæsenets behandlinger, hvilket for undertegnede lyder som sandt paradis af lige præcis den New Public Management, der forsøges gjort op med.

Et andet vigtigt spørgsmål, som bogen giver anledning til at diskutere, er forholdet mellem sundhedsprofessionernes autonome opgavevaretagelse og indretningen af den offentlige sundhedspolitik. På den ene side er det i mange lande sådan, at en stærk lægeprofession reelt indskrænker beslutningsrummet for den offentlige sundhedspolitik. Det ses aller klarest i den amerikanske lægeforenings (AMA) århundredelange blokering af offentlig sygesikring, og hvor AMA's egne ideer om udstrækningen af deres professionelle ekspertise strækker så langt, at der ikke er meget tilbage for politikere at beslutte. På den anden side peger LH på den modsatte dynamik, hvor forventningerne til sundhedsvæsenet bliver skruet op af den partipolitiske konkurrence i den nationale sundhedspolitiske arena. Her har LH helt klart fat i en vigtig diskussion, fordi alle undersøgelser viser, at vælgerne gerne vil have flere ressourcer til sundhedsvæsenet, hvilket politikerne så konkurrerer om at kunne levere. Det giver ikke nødvendigvis flere ressourcer til alle områder, da der altid er mere vilje til at udstede dyre garantier til kræftpatienter, end der er til mindre prestigiøse områder som psykiatri og socialmedicin. Det ændrer dog ikke ved, at de overordnede rammer for det danske sundhedsvæsen er i vækst og har gennemgået en ret voldsom udvidelse siden årtusindskiftet.

LH stiller sig ret skeptisk over for, om sundhedsudgifterne nu rent faktisk er steget så meget som påstået. Det fremføres i stedet, at udgiftsvæksten blot er en påstand, der bliver fremført af sundhedsministeriet til at afvise lægernes påstand om manglende ressourcer eller sende den videre til regionerne. Det er dog lidt uklart, hvorvidt LH rent faktisk bestrider, at sundhedsvæsenet har gennemgået en betydelig vækst, eller om argumentet mere er, at den overordnede vækst er blevet udvandet af at skulle 
Tema: Professionshøjskoler i 10 år

fordeles ud på langt flere opgaver. Det er helt korrekt, at der på de fleste områder leveres langt flere behandlinger end tidligere, og mange behandlingsforløb er i dag mere komplicerede og involverer derfor flere indgreb, blodprøver, tests osv. end tidligere. Det er ligeledes korrekt, at en del af væksten sandsynligvis er blevet ædt op af dyrere medicin og vækst i andre faste omkostninger.

Igen er det amerikanske sundhedsvæsen et glimrende eksempel på, at det er muligt at bruge ufatteligt mange ressourcer på sundhed - hvad enten pengene bruges i offentligt eller privat regi-uden nødvendigvis at få ret meget sundhed for pengene. Men er det et argument for, at vi får et bedre sundhedsvæsen ud af at øge udgifterne, mens vi samtidig overlader ledelsen til de sundhedsprofessionelles 'faglighed' som eneste præmis? Det er jeg langt fra overbevist om. Hvis LH har ret $\mathrm{i}$, at der trods den overordnede vækst i systemet hele tiden bliver mindre og mindre tid til den enkelte sundhedsprofessionelles møde med patienterne - og det tror jeg er en korrekt diagnose - handler det vel om få analyseret og prioriteret blandt de mellemliggende led, der sluger ressourcerne eller øger presset på antal behandlinger, som skal køres igennem maskinen?

Her vil jeg argumentere for, at LH er alt for hurtig til at se djøfisering som roden til unødigt ressourceforbrug og de sundhedsprofessionelles faglige autonomi som det løsen, der på magisk vis kan skabe mere sundhed for de samme penge. Det er muligvis rigtigt, at de sundhedsprofessionelle havde større arbejdstilfredshed, før de fra 1980'erne og frem blev sendt igennem kavalkader af ledelsesreformer, effektiviseringer og kvalitetsmålinger. På den anden side viser LH's egne tabeller jo selv, at antallet af behandlinger er steget markant i den samme periode, så man kunne jo rejse det spørgsmål, om effektiviseringerne måske ligefrem havde virket, selvom de færreste bagefter ville gå ud og rose en effektiviseringsplan? I hvert fald gør det det vanskeligt at se, hvordan sundhedsvæsenet kan vende tilbage til den gyldne periode før NPM uden samtidig at vende tilbage til et system, der enten akkumulerer ventetid, som det skete i 1980'erne, eller som om ikke andet må have tilført markant flere ressourcer for at kunne behandle nutidens antal patienter med den service og fleksibilitet, som de nu engang er blevet vant til at forvente fra det offentlige.

Mit argument er overordnet set ikke, at LH's beskrevne problemer ikke findes, eller at de foreskrevne løsninger er helt ubrugelige. Jeg mener dog, at bogen generelt bærer præg af på den ene side at kæmpe meget hårdt for større respekt for professionel faglighed, men samtidig at være helt afvisende over for, at andet end sundhedsprofessionelle overhovedet fortjener betegnelsen 'faglighed'. Har økonomer en professionel faglighed, der kvalificerer dem til at vide mere om optimering, økonomistyring end manden på gaden, eller end HK'ere havde i fortidens sundhedsvæsen? Det synes ikke at være LH's opfattelse.

Et andet problem er, at LH er lige lovlig hurtig til at se tabuer og undertrykte diskurser alle de steder, hvor lægefaglige synspunkter bliver modsagt eller overtrumfet af andre hensyn. Fx hævdes det, at sundhedsudgifterne reelt ikke er så høje set i forhold til, at udgifterne til overførselsindkomster er endnu højere, hvilket angiveligt er et 'tabu' (s. 28). Det er mig helt ubegribeligt, hvordan nogen kan mene, at det skulle være et tabu, eftersom stort set alle velfærdsreformer de seneste tyve år har haft som erklæret mål at flytte store grupper af borgerne fra overførsler til arbejdsmarkedet. Det hævdes ligeledes, at lægernes kritiske stemmer undertrykkes i den offentlige debat, fordi nogle andre end lægerne 'ejer' diskursen, således at lægernes kritikker ikke bliver imødekommet. Det er naturligvis uacceptabelt, hvis professionelle ikke tør ytre sig kritisk om den offentlige sektors indretning. Alligevel klinger det noget hult, at lægers diskurs eller professionelle stemme angiveligt skulle være undertrykt i den offentlige debat om sundhedspolitik. Hver eneste dag er aviserne fyldt med sundhedsprofessionelles kritik af $\mathrm{fx}$ Sundhedsplatformen. LH giver selv en række eksempler på, at overlæger, der har sagt op i protest mod sundhedsvæsenet, har været på forsiden af aviserne. Men er man en undertrykt stemme eller en tabuiseret professionel faglighed, hvis man som faggruppe har direkte adgang til Politikens forside? Spørgsmålet er i hvert fald, om det egentlig er lægeprofessionens ret til at ytre sig og blive hørt, der er på spil, eller om det i virkeligheden er de professionelles ret til ikke at blive modsagt, der på tale? 